Studia z Dziejów Średniowiecza nr 21, 2017

\author{
Krzysztof Kwiatkowski
}

(Toruń)

\title{
Niewola księcia pomorsko-szczecińskiego Kazimierza [V] po bitwie grunwaldzkiej (1410/1411) - obserwacje historycznokulturowe
}

Key words: Battle of Grunwald, Casimir V, Pomerania, war in the Middle Age, pilgrimage, captivity

Działania wojenne prowadzone podczas konfliktu Królestwa Polski i Wielkiego Księstwa Litewskiego z zakonem niemieckim w latach 1409-1411 r. na obszarach (zachodnio)pomorskich oraz na pograniczu Pomorza Zachodniego i Wschodniego (Gdańskiego) przyniosły bliżej niemożliwe do oszacowania straty osobowe zarówno wśród zbrojnych/ wojowników z kontyngentów poszczególnych władców (zachodnio) pomorskich, w różnych okresach bioracych aktywny udział w przedsięwzięciach militarnych po jednej bądź drugiej stronie sporu, jak również wśród pozostałej ludności ziem (zachodnio)pomorskich, zwłaszcza tych położonych nieopodal granic terenów podlegających zwaśnionym władcom. Trzeba również zaznaczyć, że w świetle wiedzy dotyczącej dobrze rozpoznanych konfliktów rozgrywających się w tym samym XV stuleciu na innych obszarach Rzeszy - którą można traktować jako solidny materiał komparatystyczny dla terytoriów pomorskich $^{1}$ - także mieszkańcy rejonów, gdzie odbywały się koncentracje

1 Por. m.in.: V. Schmidtchen, Ius in bello und militärischer Alltag - Rechtliche Regelungen in Kriegsordnungen des 14. bis 16. Jahrhunderts [w:] Der Krieg im Mittelalter und in der Frühen Neuzeit: Gründe, Begründungen, Bilder, Bräuche, Recht, hg. v. H. Brunner, Imagines medii aevi. Interdisziplinäre Beiträge zur Mittelalterforschung, Bd. 3, Wiesbaden 1999, s. 39-42; ostatnio zaś niezwykle poglądowo G. Zeilinger, Lebensformen im Krieg. Eine Alltags- und Erfahrungsgeschichte des süddeutschen Städtekriegs 1449/50, Vierteljahrschrift für Sozial- und Wirtschaftsgeschichte, Beihefte, 
znaczniejszych grup zbrojnych i przez które biegły szlaki pochodów poszczególnych zgrupowań, mogli ucierpieć podczas tego rodzaju akcji militarnych, nierzadko nawet tracac życie. Nic konkretnego o bezpośrednich następstwach poszczególnych akcji militarnych z lat 1410-1411 dla ludności Pomorza Zachodniego jednak nie wiadomo. Znane są szczątkowe dane dotyczące zniszczeń dokonanych głównie jesienią i zimą 1410/1411, tudzież wiosną 1411 r. na terytorium szczecineckim władztwa Bogusława VIII². Podejmowane wówczas przedsięwzięcia militarne w północnym sektorze pogranicza pomorsko-pruskiego - między Pomorzem Zachodnim a Pomorzem Wschodnim (Gdańskim) - miały zasadniczo charakter napadów rabunkowych najpewniej niewielkich grup zbrojnych i prawdopodobnie, mimo możliwej znacznej intensywności, ich efektywność w zakresie destrukcji była często ograniczona.

Wśród bezpośrednich następstw konfliktu 1409-1411 r. na Pomorzu Zachodnim jedno z nich wyróżnia się jednak zasadniczo. Miało ono bowiem charakter stosunkowo krótkoterminowy, zarówno jeśli chodzi o jego istnienie, jak i oddziaływanie. Trwało dłużej aniżeli sam konflikt polsko-litewsko-zakonny 1409-1411 r., a zarazem znacznie krócej aniżeli ukształtowane w jego rezultacie nowe sieci powiązań regionalnych czynników politycznych. Wypada go zarazem określić jako jeden z najbardziej bezpośrednich znanych skutków starcia grunwaldzkiego. Chodzi mianowicie o tytułową niewolę księcia pomorsko-szczecińskiego Kazimierza [V]. Zgodnie z decyzją króla Władysława II i jego doradców, podjętą na pobojowisku 16 lipca 1410 r., miał się on stawić z okupem w Krakowie w dniu św. Marcina (tj. 11 listopada) ${ }^{3}$, przy czym 29 sierpnia w obozie pod

Bd. 196, Stuttgart 2007; i w sposób bardziej syntetyzujący H.-H. Kortüm, Kriege und Krieger 500-1500, Stuttgart 2010, s. 241-260.

2 Por. w tej kwestii moje uwagi wprowadzające, zob. K. Kwiatkowski, Nowa Marchia w działaniach militarnych 1410-1411 roku [w:] Santok i Drzeń w konflikcie polsko-krzyżackim. W 600. rocznice bitwy pod Grunwaldem. Wydawnictwo pokonferencyjne 22 czerwca 2010 roku, red. W. Popek, Gorzów Wielkopolski 2012, s. 85-88 (tu również krytyka niektórych starszych przyczynków dotyczących tej tematyki).

3 Joannis Dlugossii Annales seu Cronicae incliti Regni Poloniae [dalej jako źródło: Długosz; jako komentarze wydawców: Annales], lib. X-XI (1406-1413), ed. K. Baczkowski et al., Varsaviae 1997, s. 125; Das Soldbuch des Deutschen Ordens 1410/1411. Die Abrechnungen für die Soldtruppen [dalej: SBDO], bearb. v. S. Ekdahl, Th. 2: Personengeschichtlicher Kommentar und Indices, Köln-Wien 2010 (,Veröffentlichungen aus den Archiven Preußischer Kulturbesitz", Bd. 23/2), Nr. 253, s. 127; GSPK, XX. HA, OBA 1374. 
Malborkiem polski monarcha za poręczeniem Bogusława VIII i siedmiu panów (zachodnio)pomorskich zwolnił księcia z obowiązku przebywania w niewoli do owego jesiennego terminu ${ }^{4}$. Wbrew opinii Grzegorza J. Brzustowicza nieznana jest suma wykupna orzeczona dla Kazimierza, nie ulega jednak wattpliwości, że musiała ona być znaczna z uwagi na monarszą rangę jeńca ${ }^{5}$. Wiadomo, że książę mimo zwolnienia z niewoli za poręczeniem nie wrócił przed 18 października 1410 r. do domu, skoro jego ojciec, książę pomorsko-szczeciński Świętobor I, pisał tego dnia w jego sprawie do pełniącego obowiązki

4 Codex Diplomaticus Regni Poloniae et Magni Ducatus Lithuaniae, ed. M. Dogiel, t. I, Vilnae 1758 („Pomerania”, Nr. VII), s. 573-574: „Significamus tenore presentium, quomodo ad fidem, promissionem et ad manus ac ad fideiussoriam cautionem preclarum principe dominum Kasimirum ducem Stetinensem, filium domini ducis Swethoborii in conflictu cum Cruciferis habito captum et detentum a serenissimo principe et domino, domino Vladislai rege Polonie, fratre et domino nostro gratioso subrigavimus et recepimus de captivitate memorata, quem sub fide et honore Christiani ad manus horum infra scriptorum baronum [...], vel eius, qui tunc fuerit Cracovie capitaneu in festo S. Martini nunc instantis in castro Cracoviensi christianice statuere promittimus, nulla penitus excusatione obsistente [...]"; por. też Długosz X/XI, s. 135; J. Mielcarz, Stanowisko Bogustawa VIII wobec konfliktu polsko-krzyżackiego w latach 1403-1411, „Rocznik Koszaliński” 1974, t. 10, s. 16, błędnie uważał, że w kwestii Kazimierza V książę pomorsko-słupski niczego pod Malborkiem od polskiego monarchy nie uzyskał - przeciwnie, należy sądzić, że raczej sporo: warunkowe zwolnienie krewnego z niewoli. Natomiast zupełnym nieporozumieniem jest opinia G.J. Brzustowicza, O udziale księcia szczecińskiego Kazimierza $V w$ bitwie pod Grunwaldem, PZ 2006, t. 21 z. 3, s. 42; o uwięzieniu księcia przez króla polskiego, zamiarze wypuszczenia go jeszcze w lecie 1410 r., a następnie o wyznaczonym na październik $1410 \mathrm{r}$. terminie uwolnienia.

5 O dużej wysokości sumy wykupnej za obu książąt wspomina Thomas Kantzow w ostatniej redakcji swojej kroniki, por. Th. Kantzow, Chronik von Pommern in hochdeutscher Mundart [dalej: Kantzow], hg. v. Georg Gabel, Bd. I: Letzte Bearbeitung, Stettin 1897, s. 241-242, ale jest to źródło stosunkowo późne, co do którego interpretacji należy zachować pewną ostrożność; G.J. Brzustowicz, O udziale księcia szczecińskiego Kazimierza V..., PZ 2006, t. 21, z. 3, s. 44 przytacza sumę 40 grzywien i 100 guldenów, zawartą w opublikowanym przez Svena Ekdahla wykazie zakonnym, zupełnie nie rozumiejąc tekstu źródła i traktując ją jako sumę okupu wypłacona „przez panów z Malborka”. Mamy tu do czynienia z niewłaściwą interpretacja treści przekazu źródłowego. Chodzi bowiem w rzeczywistości o pieniądze (40 grzywien pruskich i 100 guldenów węgierskich = łącznie 290 grzywien pruskich), które księciu zostały wypłacone przez braci zakonu niemieckiego w czasie jego pobytu w obozie królewskim pod oblężonym Malborkiem jako strawne (czerunge), por. SBDO, Th. I: Text mit Anhang und Erläuterungen, Köln-Wien 1988 (,Veröffentlichungen aus den Archiven PreuBischer Kulturbesitz”, Bd. 23/1), s. 187. Książę otrzymywał je (łącznie równowartość niemal 272 grzywien pruskich) także później, jesienią 1410 r., kiedy przebywał już najprawdopodobniej na obszarze Królestwa Polskiego, por. przyp. 8. 
wielkiego mistrza komtura świeckiego Heinricha von Plauen ${ }^{6}$. Należałoby to łączyć najprawdopodobniej z niemożnością zebrania przez książąt pomorsko-szczecińskich (Świętobora I i jego starszego syna Ottona [II]) pełnej sumy wykupnej ${ }^{7}$ na 11 listopada, co przyszłą pełna wolność Kazimierza stawiało pod znakiem zapytania. Dalszy pobyt księcia w Królestwie Polski po zakończeniu wyprawy letniej 1410 r. zdają się potwierdzać również wspominane wyżej zapisy zakonne, wskazujace, że w tym czasie otrzymał on od braci zakonnych strawne (czerunge) wysokości 20 nobli angielskich i następnie 500 guldenów węgierskich (łącznie ówczesna równowartość prawie 272 grzywien pruskich $)^{8}$. Wiadomo też, że drugi z wziętych do niewoli monarchów, książę oleśnicki Konrad [VII] Biały jesienią 1410 r. bądź wiosną 1411 r. wyjechał na Litwę ${ }^{9}$. Najprawdopodobniej podobny los spotkał

6 GSPK, XX. HA, OBA 1374: „Lieben heren und vrunde, ir wyzzet wol, dat unser so ${ }^{\circ} \mathrm{n}$ herczog Kazemer in des Ordens dinste von dem Orden abe ghefangen ist, und der $m u^{c} z u^{c} t^{c} u^{c}$ santte Mertens dage dem konighe von Polen wydder yn komen, und wy faren sere, daz der konich umbe der grozzen unghunst, der her tzu euwerm Orden hat und tzu e uns umbe des Ordens willen, unser son mach verlich von swarlich syn, unde mochte en alse weyt vorsenden ader ander swarheyt an legen, daz uns und den unsern unvorwinlich were. Nu der konich, got sy ghelobet, wydder wech gherumet ist, alzo daz ir euwer slozze von des euwern wedder macht habt. Nu byte wir euch myt allen flyzze, dar ir dar tzu ${ }^{\mathrm{c}}$ trulichen arbeyt von dencken, daz unser son werde, und daz hobe wer vor befolen herre Michel Kuchmester, euwern voyth in der Marke, dar her by uns was tzu ${ }^{\mathrm{e}}$ Treben by Arnswalde, der saght uns daz trulich tzu ${ }^{\mathrm{e}}$ werben und eyn antwerd tzu schyckende, daz noch nicht ghescheen ist. Hir umbe bitte wer noch, daz ir uns eyn hulffelich antwerde screbet, hir mete vyle guter nacht”.

7 W literaturze niejednokrotnie błędnie przyjmowano, że wykupu Kazimierza [V] z niewoli królewskiej dokonał zakon niemiecki, por. m.in. H. Branig, Geschichte Pommerns, Th. I: Vom Werden des neuzeitlichen Staates bis zum Verlust der staatlichen Selbstständigkeit 1300-1648, bearb. v. W. Buchholz, Köln-Weimar-Wien 1997 (Veröffentlichungen der Historischen Kommission für Pommern, Reihe V: „Forschungen zur pommerschen Geschichte”, Bd. 22/I), s. 47. Nie ma ku temu żadnych przesłanek źródłowych.

8 SBDO I, Anh. 24 (A), s. 187-188; Anh. 24 (B), s. 199-200.

9 SBDO I, Anh. 24 (B), s. 190; por. też Anh. 24 (A), s. 180. Biorąc pod uwagę fakt, że Kazimierz V przebywał jesienią 1410 r. w Królestwie [por. SBDO I, Anh. 24 (B), s. 199], można wnioskować, że zwycięscy monarchowie, Władysław II i Aleksander Witold, podzielili się po równo jeńcami o najwyższej, książęcej godności, tak że jeden pozostał w niewoli wielkiego księcia litewskiego, a drugi króla polskiego. Pobyt obu książąt w dwóch różnych krajach (in den landen) władanych przez obydwu wspomnianych monarchów, a więc jednego na Litwie, a drugiego w Królestwie Polski, potwierdza zapis odpowiedzi uzyskanych przez poselstwo zakonne u tychże władców wiosną $1411 \mathrm{r}$., por. Codex epistolaris Vitoldi Magni Ducis Lithuaniae 1376-1430 [dalej: CEVMDL], ed. A. Prochaska, „Monumenta Medii Aevi Historica”, t. VI, pars 1-2, Wydawnictwa Komisyi Historycznej Akademii Umiejętności w Krakowie, Nr. 23, Cracoviae 1882, 
w połowie marca 1411 r. również Kazimierza, aczkolwiek w innych okolicznościach, bowiem jego wymuszona podróż wiązała się zapewne z podjętym wówczas przez króla polskiego triumfalnym objazdem ziem litewskich i ruskich ${ }^{10}$. Takie zresztą obawy odnośnie do możliwego wysłania przez króla Polski przetrzymywanego w niewoli księcia pomorsko-szczecińskiego daleko od domu (alse weyt vorsenden ${ }^{11}$ wyrażał Świętobor I w przywołanym liście do Heinricha von Plauen z 18 października. Jest także pewne, że obu książąt nie objęły postanowienia rozejmu z 7 grudnia ${ }^{12}$ ani układu z 31 stycznia, ani wreszcie pokoju z 1 lutego $1411 \mathrm{r} .{ }^{13}$ Obaj uzyskali listy zwalniajace z niewoli wystawione przez Władysława II i Aleksandra Witolda w Wilnie dopiero 8 czerwca 1411 r. ${ }^{14}$, a więc ponad sześć miesięcy po pierwot-

pars 1 , nr 467, s. 217; co do ich datacji na okres po 15 marca por. M. Pelech, W sprawie okupu za jeńców krzyżackich z wielkiej wojny (1409-1411), cz. I, ZH 1987, t. 52, z. 1, s. 139 , przyp. 40.

10 W tej kwestii przeprowadzam szerszą analizę w znajdującym się w przygotowaniu artykule, zob. K. Kwiatkowski, Rex nicht nur, bellator' und,ambulans', aber auch ,ostendens‘. Das Kommunizieren vom Schlachtensieg als Herrschaftsmittel im spätmittelalterlichen Mittelosteuropa; por. też W. Fałkowski, Adventus regis. Powrót Wtadystawa Jagietty do Krakowa po zwycięstwie grunwaldzkim, RH 2010, R. 76, s. 77.

11 Por. treść źródła w przyp. 6.

12 Lites, wyd. 2, red. I. Zakrzewski, t. II, Poznań 1892, Add. LXIII.

13 Lites 2/II, Add. LXVI, s. 461-464. Błędne mniemanie w tej kwestii wyraził niedawno G.J. Brzustowicz, O udziale księcia szczecińskiego Kazimierza V..., s. 42, pisząc o „porozumieniu w sprawie Kazimierza i innych jeńców zawartym [...] 1 lutego 1411 roku”, zresztą wbrew treści przytaczanych przez siebie źródeł, por. ibidem, s. 44-45, przyp. 84. Potwierdzałyby to wspomniane już wyżej zapisy zawierające treść odpowiedzi króla Polski i wielkiego księcia Litwy, jaką otrzymali wiosną $1411 \mathrm{r}$. posłujący do nich ze strony wielkiego mistrza komturzy: brandenburski Ulrich Zenger i ragnecki Helferich von Drahe, por. CEVMDL I 467, s. 217.

14 A więc zupełnie niezależnie od terminów spłat poszczególnych rat $100 \quad 000$ kop groszy, por. GSPK, XX. HA, Pergamenturkunden [dalej: Perg.-Urk.], Schiebl. 64, Nr. 9; Codex epistolaris saeculi decimi quinti (1384-1492), t. II (1382-1445), ed. A. Lewicki, Wydawnictwa Komisyi Historycznej Akademii Umiejętności w Krakowie, Nr. 46, Cracoviae 1891 („Monumenta Medii Aevi Historica”, t. XII, nr 37), s. 45-46; por. S.M. Kuczyński, Wielka wojna z Zakonem Krzyżackim w latach 1409-1411, Warszawa 1987, s. 456, przyp. 101; J. Mielcarz, Stanowisko Bogustawa VIII wobec konfliktu polsko-krzyżackiego..., s. 15; J. Zdrenka, Polityka zagraniczna ksiażat szczecińskich w latach 1295-1411, Słupsk 1985 (,Biblioteka Słupska”, t. 34), s. 265; Annales X/XI, s. 142, przyp. 446; G.J. Brzustowicz, O udziale księcia szczecińskiego Kazimierza V..., s. 45. Następnie poświadczony jest jako wolny dopiero 25 XI 1411 r. i 9 I 1412 r., por. CDBrand., Th. 1, Bd. XIX, Berlin 1860, Nr. 208, s. 310-311; Verzeichni $\beta$ der von Dregerschen übrigen Sammlung Pommerscher Urkunden zur Fortsetzung deßen Codocis Pomeraniae vicinarumque terrarum diplomatici, hg. J.C.C. Oelrichs, Alten-Stettin 1795, Jahr 1412, no. 3, s. 114. 
nie ustalonym terminem świętomarcińskim 1410 r. i cztery miesiące po układzie pokojowym, aczkolwiek i ów akt prawny nie wiązał się $\mathrm{z}$ ich faktycznym uwolnieniem. Trudno dociec, czy termin wystawienia listów zwalniających zależał wyłącznie od czasu dostarczenia przez nich sum wykupnych, czy był związany również z akcją dyplomatyczną wielkiego mistrza Heinricha von Plauen, ślącego wiosną $1411 \mathrm{r}$. w tej sprawie list suplikacyjny do polskiego monarchy ${ }^{15}$. Tej ostatniej możliwości nie można zupełnie wykluczyć, jeśliby uwzględnić opisana przez Jana Długosza na kartach Banderia Prutenorum wrogość Władysława II do szczecińskiego Gryfity, wedle wyjaśnień krakowskiego kanonika wynikająca z działania księcia na szkodę Królestwa Polski, wbrew tradycji jego przodków z domu gryfickiego, którzy mieli wiernie służyć polskim monarchom ${ }^{16}$. Wydaje się, że obraz nakreślony przez polskiego dziejopisa może opierać się na jakiejś dworskiej tradycji - tym bardziej że chodziło tu o sprawy między monarchami - i odzwierciedlać rzeczywistość z 1410 r., wskazywałyby na to bowiem inne przesłanki pośrednie, a mianowicie omówione

15 List wielkiego mistrza datowany z Sątoczna (niem. Leunenburg) 21.03.1411 r. nie dochował się do naszych czasów, dysponujemy jednak kilkoma jego regestami (por. Skarbiec dyplomatów papiezkich, cesarskich, krolewskich, ksiażęcych; uchwat narodowych, postanowień różnych władz i urzędów posługujacych do krytycznego wyjaśnienia dziejów Litwy, Rusi litewskiej i ościennych im krajów, t. II, wyd. I. Daniłowicz, Wilno 1862, nr 956, s. 3 (=Index actorum saeculi XV ad res publicas Poloniae spectantium, ed. A. Lewicki, Wydawnictwa Komisyi Historycznej Akademii Umiejętności w Krakowie, Nr. 41, Cracoviae 1888 („Monumenta Medii Aevi Historica”, t. XI), nr 610, s. 74); edycją (aczkolwiek z błędną data) z początku XX w. (por. S. Kujot, Rok 1410. Wojna, „Roczniki Towarzystwa Naukowego w Toruniu” 1910, R. 17, s. 347-350, dod. nr 7); oraz opisem Johannesa Voigta [por. J. Voigt, Geschichte Preussens von den ältesten Zeiten bis zum Untergange der Herrschaft des Deutschen Ordens, Bd. VII: Die Zeit vom Hochmeisters Ulrich von Jungingen 1407 bis zum Tode Hochmeisters Paul von Rußdorf 1441, Königsberg 1836 (repr.: Hildesheim 1968), s. 144], który zapisy z „Registrantu Wielkomistrzowskiego II” („Hochmeister-Registrant II”), późniejszego, zaginionego w 1944 r., „Ordensfolinatu 5” (OF 5), znał z autopsji; por. też M. Pelech, Der verlorene Ordensfoliant 5 (früher Hochmeister-Registrant II) des Hist. Staatsarchivs Königsberg, mit Regesta (nach Rudolf Philippi und Erich Joachim) [w:] Beiträge zur Geschichte des Deutschen Ordens, Bd. 1, hg. v. U. Arnold, Marburg 1986, QSGDO 36, Veröffentlichungen der Internationalen Historischen Kommission zur Erforschung des Deutschen Ordens, Bd. 1, s. 141, Regest nr 19.

16 S. Ekdahl, Die „Banderia Prutenorum” des Jan Dtugosz - eine Quelle zur Schlacht bei Tannenberg 1410. Untersuchungen zu Aufbau, Entstehung und Quellenwert der Handschrift. Mit einem Anhang: Farbige Abbildungen der 56 Banner, Transkription und Erläuterungen des Textes [dalej jako źródło: Banderia (E)], Göttingen 1976 (,Abhandlungen der Akademie der Wissenschaften in Göttingen, Philologisch-historische Klasse, Dritte Folge”, Nr. 104), s. 252. 
poniżej działania podejmowane przez Świętobora I, jak i sam jego list z 18 października 1410 r. ${ }^{17}$

Sa jeszcze inne poszlaki potwierdzające przypuszczenie o daleko negatywnym nastawieniu Władysława II do Kazimierza, odnoszące się do okresu o kilka miesięcy późniejszego od omawianego. Mianowicie w listopadzie 1411 r. obaj bracia Otton [II] i Kazimierz [V], zapewne podczas pobytu w Vordingborgu, oddają się w opiekę i na służbę królowej Małgorzacie i Koronie Duńskiej, a więc przyjmują zwierzchnictwo ze strony zupełnie innego czynnika władczego aniżeli krag polityczny, w którym ich ojciec poruszał się przez ostatnie kilka lat ${ }^{18}$. Można przypuszczać, że jednoznacznie wrogie nastawienie Władysława II do książąt pomorsko-szczecińskich wynikające z ich opowiedzenia się w konflikcie 1409-1411 r. po stronie zakonu niemieckiego wraz z jednoczesnym nagłym spadkiem atrakcyjności sojuszu z tym ostatnim, osłabionym w wyniku konfliktu z królem Polski, miały znaczący wpływ na zakres możliwości aktywnych działań władczych tej linii Gryfitów bezpośrednio po zakończeniu wojny 1409-1411 r. Jaki wpływ na tę zmianę relacji władczych miał ich ojciec Świętobor I, wracający właśnie z dalekiej podróży (o niej niżej), a jaki od miesięcy aktywnie współuczestniczący w polityce bałtycko-skandynawskiej Warcisław VIII, trudno określić na tym etapie rozpoznania problemu. Wymagałoby to badań obejmujących szerszy kontekst zarówno wydarzeniowy, jak i strukturalny.

17 GSPK, XX. HA, OBA 1374: „[...] und wy faren sere, daz der konich umbe der grozzen unghunst, der her tzu euwerm Orden hat und tzu uns umbe des Ordens willen, unser son mach verlich von swarlich syn [...]".

18 M. Wehrmann, Geschichte von Pommern, Bd. I [Bis zur Reformation (1523)], Allgemeine Staatengeschichte, 3. Abt. Deutsche Landesgeschichten, Nr. 5, Gotha 1904, s. 171. Odnośnie do obecności Ottona II i Kazimierza V w Vordingborgu 7.11.1411 r. por. Diplomatarium Danicum [dalej: DD], 4. Række, Bd. XII: 1410-1412, nr 319, edycja elektroniczna: http://diplomatarium.dk/de_dd/diplomer/11-088.html [dostęp 20.08.2016]. Ze strony królowej duńskiej był to element szerszej akcji mającej wówczas na celu rozbudowę zakresu jej władzy i wpływów Korony Duńskiej na południowo-zachodnim pobrzeżu Bałtyku, co w trwającym akurat konflikcie szlezwickim miało ogromnie istotne znaczenie; w tym samym 1411 r. również książęta meklembursko-stargardzcy Ulrich I i Johann II weszli na służbę duńską w zamian za roczną rentę wysokości 500 grzywien lubeckich, zobowiązując się do wystawienia królowej Małgorzacie kontyngentu 100 konnych zbrojnych za kolejne 500 grzywien srebra kwartalnego żołdu; por. ostatnio O. Auge, Handlungsspielräume fürstlicher Politik im Mittelalter. Der südliche Ostseeraum von der Mitte des 12. Jahrhunderts bis in die frühe Reformationszeit, Ostfildern 2009 („Mittelalter-Forschungen”, Bd. 28), s. 49, przyp. 275; s. 85, przyp. 599 ; s. 172 , przyp. 12 ; s. 173 ; s. 290 , przyp. 224. 
Obok istotnego wymiaru politycznego przedłużająca się niewola Kazimierza jawi się w odczuciach jego ojca przede wszystkim jako wielka klęska rodzinna. Na ten ciekawy rys mentalny zwiąany z bitwa grunwaldzką wskazuje bowiem pielgrzymka odbyta przez Świętobora I w 1411 r. do Ziemi Świętej, co jednoznacznie potwierdzaja dokumenty starszego jego syna, księcia Ottona [II] wystawione 18 marca i 25 marca 1411 r., w których ten ostatni występuje jako pełnomocnik ojca, „das he buten landes was to deme Hilgen Lande" ${ }^{19}$. W dniu 21 marca 1411 r. Świętobor jest również nieobecny

19 Brandenburgisches Landeshauptarchiv Potsdam [dalej: BLHA], Pr. Br. Rep. 9 B Johanniterorden, Nr. U 213 (= regest: Allgemeine Geschichte des Geschlechts von Schwerin, hg. v. L. Gollmert, W.Hz. v. Mecklenburg-Schwerin, L.Hz. v. Mecklenburg-Schwerin, Bd. 3: Urkundenbuch zur Geschichte des Geschlechts von Schwerin [dalej: UBSchwerin], Berlin 1878, Nr. 249): 18 III 1411 r., książę pomorsko-szczeciński Otto [II] wystawia w Damme dokument dla Henninga Swochowa oraz jego brata Geverda wraz z synem Clawsem w imieniu swojego ojca Świętobora i brata Kazimierza: „vor unsen gnedigen vader hertogen Swantobur van des wegene, wy vullmechtich weren, alse he buten landes was to dem Hilgen Lande unde vor unsen 1[e]ven bruder Casymer hertogen"; por. J. Zdrenka, Itinerar des Stettiner Herzogs Swantibor I. (ca. 1351-1413), „Archiv für Diplomatik, Schriftgeschichte, Siegel- und Wappenkunde” 1995, Bd. 41, s. 191, przyp. 259; ponadto UBSchwerin 250 (tylko regest): 25 III 1411 r.; por. J. Zdrenka, Itinerar des Stettiner Herzogs Swantibor I..., s. 191, przyp. 260; idem, Polityka zagraniczna ksiażat szczecińskich..., s. 266. Książę był nieobecny w swoim władztwie także dowodnie 26 czerwca i 26 lipca tegoż roku, por. BLHA, Pr. Br. Rep. 10 B Prämonstratenserkloster Gramzow, Nr. U 3 (= regest: Urkundeninventar des Brandenburgisches Landeshauptarchivs. Kurmark, Th. 1: Landesherrliche, ständische und geistliche Institutionen, bearb. v. F. Beck, Berlin 2001 [,Veröffentlichungen des Brandenburgischen Landeshauptarchivs", Bd. 41], Nr. 2979, s. 427): 26 VI 1411 r., książę pomorsko-szczeciński Otto [II] udziela (prawdopodobnie w Passow) zgody na sprzedaż dóbr we wsi Weselitz przez panów von Arnsdorf dla klasztoru premonstratensów w Gramzow, czyniąc to „vor unsim leven vader hertoghe Swantebur”, Vorpommersches Landesarchiv Greifswald, Rep. 2, Ducalia, Nr. 225 (= regest: Geschichte des Geschlechts von Heydebreck, bearb. v. H. Hoogeweg, Bd. 1: Urkundenbuch 1245-1500, Stettin 1924, Nr. 288): 26 VII 1411 r.; por. także Archiwum Państwowe w Szczecinie, 197, Akta miasta Gryfina, nr 40, niedatowany dziennie dokument Ottona [II] z 1411 r.

Joachim Zdrenka uznawał, idąc za starszą literaturą (por. H. Heyden, Die Wallfahrtswesen in Pommern, „Blätter für Kirchengeschichte Pommerns” 1940, Bd. 22-23, s. 13; N. Buske, Die Verehrung des Hl. Ewald und die Errichtung der Bodstedter Kapelle, BS NF 1972, Bd. 58, s. 22, przyp. 20), że książę Świętobor I odbył w 1411 r. pielgrzymkę do kościoła św. Theobalda w górnoalzackim, należącym od 1324 r. do Habsburgów, mieście Thann (ca 20 km na północny zachód od Mulhouse), gdzie od końca XIII w. rozwiną się kult relikwii biskupa Ubalda (Theobalda) z Gubbio ( $\dagger$ 1160). Znana jest bowiem jego podróż do owego sanktuarium w czerwcu-wrześniu 1408 r., por. N. Buske, Die Verehrung des Hl. Ewald..., s. 22; J. Zdrenka, Itinerar des Stettiner Herzogs Swantibor I..., s. 189; idem, Święty Teobald pomocnikiem w potrzebie mieszkańców Pomorza i Prus w średniowieczu [w:] Mieszczanie, wasale, zakonnicy, 
red. B. Śliwiński, Malbork 2004, („Studia z Dziejów Średniowiecza”, nr 10), s. 395, 402-403 (tu przekaz źródła); w kwestii sanktuarium oraz jego popularności w nadbałtyckich krajach Rzeszy w XV w. por. F. Rapp, Thann (hasło) [w:] Lexikon des Mittelalter [dalej: LMA], hg. v. R.-H. Bautier, Bd. VIII, Stuttgart-Weimar 1999, szp. 610-611; B. Henze, Thann (hasło) [w:] Lexikon für Theologie und Kirche [dalej: LThK], hg. v. W. Kasper, Bd. 9, Freiburg-Basel-Rom-Wien 2000, szp. 1381; M.-L. Favreau-Lilie, The German Empire and Palestine. German Pilgrimages to Jerusalem between the $12^{\text {th }}$ and the $16^{\text {th }}$ Century, „Journal of Medieval History” 1995, vol. 21, no. 4, s. 325. Opinia J. Zdrenki nie jest trafiona. Za wskazywaną przez zielonogórskiego historyka pielgrzymką alzacką w 1411 r. przemawiałby jedynie fakt, że św. Theobald był uznawany za patrona pomagającego jeńcom odzyskać wolność, jednak wypada zauważyć, że Świętobor I od swojego pobytu w Thann w 1408 r. corocznie przesyłał na rzecz sanktuarium jałmużnę wysokości 6 guldenów, por. N. Buske, Die Verehrung des Hl. Ewald, s. 22, przyp. 20. Pomoc świętego zatem miał niejako zapewniona. Wobec jednoznaczności przytoczonych wyżej przekazów źródłowych wyjazd Świętobora I do Alzacji w 1411 r. należy jednak uznać ostatecznie za wykluczony. Natomiast właściwie, aczkolwiek bardzo syntetycznie, odnośnie do geograficznego celu pielgrzymki Świętobora I wypowiedział się przed ponad 50 latami Hellmuth Heyden, zob. H. Heyden, Kirchengeschichte Pommerns, Bd. I: Von den Anfängen des Christentums bis zur Reformationszeit, Köln-Braunsfeld 1957 (,Osteuropa und der deutsche Osten. Beiträge aus Forschungsarbeiten und Vorträgen der Hochschulen des Landes Nordrhein-Westfalen, Reihe III: Westfälische Wilhelms-Universität zu Münster”, Bd. 5), s. 148, zestawiając ją m.in. z innymi italskimi i palestyńskimi podróżami odbytymi w latach 1392-1393 i 1406-1407 r. przez Warcisława VIII oraz lewantyńska wyprawą Eryka XIV z 1424 r. O tych peregrynacjach por. J. Zdrenka, Die Pilgerfahrten der pommerschen Herzöge ins Heilige Land in den Jahren 1392/1393 und 1406/1407, BS NF 1995, Bd. 81, s. 7-17. Sam Świętobor pielgrzymował prawdopodobnie do Rzymu w 1392/1393 r. lub w 1395 r., por. J. Zdrenka, Itinerar des Stettiner Herzogs Swantibor I...., s. 180, który jednak sytuuje (z pewnym tylko prawdopodobieństwem) obecność księcia pomorsko-szczecińskiego w Wiecznym Mieście na lato 1392 r., zamiast łączyć wzmiankę pomorskiego monarchy w przywoływanym przez F.W. Bartholda (por. idem, Geschichte von Rügen und Pommern, Th. III: Vom Tode Barnims I. (1278) bis zum Auftreten der Hohenzollern in der Mark Barndenburg (1411), Hamburg 1842, s. 547) dokumencie odpustowym Bonifacego IX z 1395 r. z możliwą pielgrzymką odpustową Świętobora I do Rzymu wiosną-latem 1395 r., która dobrze wpisywałaby się w znane dotychczas itinerarium księcia, por. J. Zdrenka, Itinerar des Stettiner Herzogs Swantibor I..., s. 182.

Stąd jerozolimska peregrynacja księcia w 1411 r. nie wydaje się $\square$ przy jednoznacznej wymowie dokumentów $\square$ podlegać żadnym wątpliwościom. Nie należy jednak oceniać tej dalekiej podróży Świętobora I jako czegoś niezwykłego czy niemożliwego, choć dla 60-letniego mężczyzny mogła być wymagającym wyczynem. W XIII w. podróż z Wenecji do Ziemi Świętej trwała statkiem od 20 do 50 dni, zależnie od stanu pogody, podobnie jak kurs z Akkonu do Mesyny w niesprzyjających warunkach atmosferycznych mógł zająć nawet do 50 dni, ale już prowadzona przy sprzyjających wiatrach podróż z Wenecji do Kandii na Krecie zajmowała jedynie 18 dni, przeciętnie zaś 23-30 dni. Jest również znany czas trwania żeglugi z Genui do Akkonu - wynosił około 1 miesiąca, por. N. Ohler, Reisen im Mittelalter, Zürich-München 2004, s. 110, 112; M. Tymowski, Horyzonty geograficzne Europejczyków w okresie rozkwitu średniowiecza (X-XIII w.) [w:] Rozkwit średniowiecznej Europy, red. H. Samsonowicz, Warszawa 2001, s. 487. Dużo zatem zależało od pogody, zaś zestawiając znane dane późnośredniowieczne dotyczące długości podróży na Morzu Śródziemnym, żeglugę między Wenecją a Akko- 
przy hołdzie miast i rycerzy środkowomarchijskich składanym przedstawicielom Zygmunta Luksemburskiego, rycerzowi pasowanemu Wendowi von Eulenburg i prepozytowi berlińskiemu Johannowi von Waldau ${ }^{20}$, podczas gdy odbiorca tego rodzaju aktu winien być sam książę jako ówczesny jeszcze namiestnik w Marchii Środkowej ${ }^{21}$. Ponownie w regionie nadbałtyckim Świętobor I jest poświadczony dopiero 11 listopada 1411 r. w Berlinie ${ }^{22}$.

Wymowę analizowanej tu dalekiej podróży Świętobora I do Lewantu uwydatnia fakt, że ową kilkumiesięczną peregrynację odbył 60-letni starzec ${ }^{23}$, majaccy zresztą niemałe kłopoty zdrowotne ${ }^{24}$.

nem można byłoby z pewną dozą ostrożności szacować na około 4-6 tygodni. W XV w. funkcjonowała praktyka sezonowych kursów okrętów z pielgrzymami z portów italskich w kierunku Lewantu, które przypadały na wczesną wiosnę (passagium martii, passagium paschale) i na sierpień (passagium augusti), por. N. Mayr, Die Reiselieder und Reisen Oswalds von Wolkenstein, Innsbruck 1961 („Schlern-Schriften”, Nr. 215), s. 47; przy czym sam pobyt w Ziemi Świętej zazwyczaj nie przekraczał 2 tygodni. Uwzględnienie wszystkich tych czynników natury fizycznej wskazuje wyraźnie, że między lutym a sierpniem/początkiem listopada 1411 r. książę pomorsko-szczciński miał aż nazbyt czasu, aby odbyć podróż z Pomorza do Lewantu, a następnie stamtąd wrócić.

${ }^{20}$ Berichte Engelberts Wusterwitz über Ereignisse seiner Zeit [dalej: Wusterwitz (R)] [w:] CDBrand., Th. IV, Bd. I, Berlin 1862, s. 38; W. Ribbe, Die Aufzeichnungen des Engelbert Wusterwitz. Überlieferung, Edition und Interpretation einer spätmittelalterlichen Quelle zur Geschichte der Mark Brandenburg [dalej: Wusterwitz (Rib)], Berlin 1973 („Einzelveröffentlichungen der Historischen Kommission zu Berlin”, Bd. 12), s. 127; por. N. Buske, Die Verehrung des Hl. Ewald..., s. 22, przyp. 20.

21 Burgrabia Friedrich VI von Nürnberg został mianowany namiestnikiem Marchii Brandenburskiej dopiero 8.07.1411 r., por. CDBrand., Th. II, Bd. III, Berlin 1846, Nr. 1295, s. 178-181 (= regest: Regesta Imperii, Bd. XI: Die Urkunden Kaiser Sigismunds (1410-1437), verz. v. W. Altmann, Bd. 1: 1410-1424, Innsbruck 1896-1897 [dalej: RI], Nr. 58); por. O. Hintze, Friedrich I., Kurfürst von Brandenburg (hasło) [w:] Neue Deutsche Biographie, hg. v. d. Historischen Kommission bei der Bayerischen Akademie der Wissenschaften, Bd. 5, Berlin 1961, s. 494.

${ }^{22}$ Historisch-diplomatische Beiträge zur Geschichte der Stadt Berlin, Th. 3: Berlinische Regesten von 949 bis 1550, hg. v. E. Fidicin, Berlin 1837, s. 290, Nr. 282; por. F.W. Barthold, Geschichte von Rügen und Pommern, Th. III, s. 625, przyp. 2; J. Zdrenka, Itinerar des Stettiner Herzogs Swantibor I..., s. 191, przyp. 263.

23 Odnośnie do daty urodzin księcia (ca 1351 r.) por. m.in. J. Zdrenka, Itinerar des Stettiner Herzogs Swantibor I..., s. 166; E. Rymar, Rodowód ksiażat pomorskich, Szczecin 2005, s. 408. Starsza literatura nie wypowiadała się w tej kwestii, por. m.in. M. Wehrmann, Swantibor III., Herzog von Pommern-Stettin (hasło) [w:] Allgemeine Deutsche Biographie, hg. v. d. Historischen Commission bei der Königlichen Akademie der Wissenschafte, Bd. 54, Leipzig 1908, s. 640;

24 Odnośnie do licznych niedogodności podczas podróży w późnym średniowieczu, zwłaszcza tych długich, por. m.in. N. Ohler, Reisen im Mittelalter..., s. 70-71, 73-78 - tu o przeprawach przez Alpy, które zapewne również musiał przebyć Świętobor, zakładając, że przynajmniej w jedną stronę przejeżdżał przez Wenecję jako główny port 


\section{Nasuwa się tu interpretacja odwołująca się do psychologii uczuć i późnośredniowiecznej mentalności ${ }^{25}$, nie ma bowiem innych}

środkowego Śródziemnomorza, w którym organizowane były morskie przewozy pielgrzymów zmierzających do Palestyny, s. 98-106 - o podróżach morskich, s. 326-329-o podróży do Palestyny; por. idem, Pilgerstab und Jakobsmuschel. Wallfahren in Mittelalter und Neuzeit, Düsseldorf-Zürich 2000, s. 108-137; idem, Pilgerleben im Mittelalter. Zwischen Andacht und Abenteuer, Freiburg-Basel-Wien 1994, s. 94-116; A. Esch, Spätmittelalterlicher Passverkehr im Alpenraum. Typologie der Quellen [w:] idem, Alltag der Entscheidung. Beiträge zur Geschichte der Schweiz an der Wende vom Mittelalter zue Neuzeit, Bern 1998, s. 173-248; Ch. Hippler, Die Reise nach Jerusalem. Untersuchungen zu den Quellen, zum Inhalt und zur literarischen Struktur der Pilgerberichte des Spätmittelalters, Frankfurt/Main-Bern-New York 1987 („Europäische Hochschulschriften”, Reihe I: Deutsche Sprache und Literatur, Bd. 968), s. 55-63, 139-161; M.-L. Favreau-Lilie, The German Empire and Palestine..., s. 326-332; J. Richard, Le transport outre-mer des croisés et des pèlerins (XII ${ }^{e}-X V^{e}$ siècles) [w:] idem, Croisades et Etats latins d'Orient, Aldershot 1992, VII, s. 27-44 (= [w:] Maritime aspects of migration, ed. K. Friedland, Köln-Wien 1989 [,Quellen und Darstellungen zur hanische Geschichte, NF" Bd. 34], s. 24-44, aczkolwiek studium dotyczy podróży przez Marsylię, a nie Wenecję, pozostaje jednak w tym kontekście bardzo poglądowe, choćby w kwestii kosztów przewozu przez Morze Śródziemne); dla Wenecji por. m.in. E. Ashtor, Venezia e il pellegrinaggio in Terra Santa nel basso Medioevo, „Archivio storico italiano” 1985, vol. 153, s. 197-223; U. Tucci, I servizi maritimi veneziani per il pellegrinaggio in Terra Santa nel Medioevo, „Studi Veneziani. Rivista annuale cura dell'Istituto di Storia della Società e dello Stato Veneziano e dell'Istituto "Venezia e l'Oriente«" 1985, n.s., vol. 9, s. 43-66; M.-L. Favreau-Lilie, Palästinareisen im späten Mittelalter. Die Bedeutung Venedigs als Einschiffungshafen, ,Jahrbuch der Berliner Wissenschaftlichen Gesellschaft" 2002, s. 137-162; D. Quirini-Popławska, Wenecja jako etap w podróży do Ziemi Świętej (XIII-XV w.) [w:] Peregrinationes. Pielgrzymki w kulturze dawnej Europy, red. H. Manikowska, H. Zaremska, Warszawa 1995 („Colloquia Varsoviensia II"), s. 126-143; M. Tangheroni, Die Pilgerrouten nach Jerusalem über das Meer [w:] Pielgerziele der Christenheit. Jerusalem - Rom - Santiago de Compostela, hg. v. Paolo C. v. Saucken, München 2010, s. 249-254; W. Schneider, Peregrinatio Hierosolymitana. Studien zum spätmittelalterlichen Jerusalembrauchtum und zu den aus der Heiliglandfahrt hervorgegangenen nordwesteuropäischen Jerusalembruderschaften, Münster 1982, s. 51; zaś w szerokim kontekście kulturowym fenomen peregrynacji palestyńskich potraktowali m.in.: U. Ganz-Blätter, Andacht und Abenteuer. Berichte europäischer Jerusalemund Santiagopilger (1320-1520), Tübingen 1990 (,Jacobus-Studien”, Bd. 4); K. Herbers, Pilgerwege im Mittelalter, Darmstadt 2005; N. Chareyron, Pilgrims to Jerusalem in the Middle Ages, New York 2000 (tu szeroka literatura przedmiotu).

${ }_{25}$ Z olbrzymiej literatury przedmiotu por. m.in.: F. Seibt, Die Krise der Frömmigkeit - die Frömmigkeit aus der Krise. Zur Religiosität des späteren Mittelalters [w:] 500 Jahre Rosenkranz 1475-1975. Erzbischöfliches Diözesan-Museum Köln, 25. Oktober 1975-15. Januar 1976, hg. v. W. Schulten, Köln 1975, s. 19-20; A. Angenendt, Grundformen der Frömmigkeit im Mittelalter, München 2004 (,Enzyklopädie deutscher Geschichte”, Bd. 68), s. 17-18, 91, 93; M.C. Díaz y Díaz, Der Pilger im Mittelalter [w:] Pielgerziele der Christenheit..., s. 39-56; L. Schmugge, Jerusalem, Rom und Santiago - Fernpilgerziele im Mittelalter [w:] Pilger und Wallfahrtsstätten in Mittelalter und Neuzeit, hg. v. M. Matheus, M. Vorträge, Bd. 4, Stuttgart 1999, s. 11-34; idem, Die Pilger [w:] Unterwegssein im Spätmittelalter, hg. v. P. Moraw, Berlin 
sposobów wyjaśnienia tej liczącej ponad 6 tysięcy kilometrów eskapady. Wypada przyjmować, że w rezultacie nieobjęcia kwestii niewoli Kazimierza postanowieniami układu toruńskiego z 31 stycznia i układu pokojowego z 1 lutego 1411 r. jego ojciec nie tylko nadal nie był pewny momentu uwolnienia syna, ale również tego, czy w ogóle jeniec zostanie zwolniony ${ }^{26}$. Prawdopodobny ówczesny pobyt Kazimierza na odległej Litwie mógł te negatywne odczucia jeszcze bardziej pogłębić.

Omawianą tu pielgrzymkę należałoby zatem traktować jako ojcowskie wotum na odzyskanie syna, w zupełności wpisujące się w ówczesną mentalność religijną i wyobrażenia o rzeczywistości ${ }^{27}$. Na tym jednak nie koniec. Jeżeli zestawimy wcześniejszą pielgrzymkę Świętobora I

1985 („Zeitschrift für Historische Forschung. Beihefte”, Bd. 1), s. 17-47; H. Kühnel, 'Werbung', Wunder und Wallfahrt [w:] Wallfahrt und Alltag in Mittelalter und Früher Neuzeit. Internationales Round-Table-Gespräch, Krems an der Donau, 8. Oktober 1990, hg. v. G. Jaritz, B. Schuh, Wien 1992 (Österreichische Akademie der Wissenschaften, Philosophisch-Historische Klasse, Sitzungsberichte, Bd. 592, Veröffentlichungen des Instituts für Realienkunde des Mittelalters und der Frühen Neuzeit, Nr. 14, s. 95-113; N. Ohler, Pilgerleben im Mittelalter..., s. 43-59; M.-L. Favreau-Lilie, The German Empire and Palestine..., s. 321-341; W. Schneider, Peregrinatio Hierosolymitana..., s. 48-51; A. Witkowska, Peregrinatio religiosa $w$ średniowiecznej Europie [w:] Peregrinationes..., s. 9-16; eadem, Peregrinatio ad loca sacra. Refleksja antropologiczno-socjologiczna, Rocz. Hum. 1979, t. 27, z. 2, s. 5-13; i w szerszym ogólnośredniowiecznym ujęciu A. Angenendt, Geschichte der Religiosität im Mittelalter, Darmstadt 2009, s. 208-212; z insularnej perspektywy angielskiej nowsze prace m.in. R.C. Fiucne, Miracles and Pilgrims. Popular Beliefs in Medieval England, New York-London 1995, zwłaszcza s. 59-82; także D. Webb, Pilgrims and Pilgrimage in the Medieval West, London 1999; zaś dla Prus S. Kwiatkowski, Klimat religijny diecezji pomezańskiej u schytku XIV $i$ w pierwszych dziesięcioleciach XV wieku, RTNT 1990, R. 84, z. 1, s. 80-91, 95-99; ponadto sumarycznie m.in.: W. Brückner, Wallfahrt. IV. Frömmigkeitsgeschichtlich (hasło) [w:] LThK, Bd. 10, Freiburg-Basel-Rom-Wien 2001, szp. 963-965; L. Schmugge, Pilger. A. Westlicher Bereich (hasło) [w:] LMA, Bd. VI, Stuttgart-Weimar 1999, szp. 2148-2150; K. Schreiner, Wallfahrten (hasło) [w:] Enzyklopädie des Mittelalters, hg. v. G. Melville, M. Staub, Bd. I, Darmstadt 2008, s. 342-343; w ujęciu antropologiczym V. Turner, E.L.B. Turner, Obraz i pielgrzymka w kulturze chrześcijańskiej, tłum. Ewa Klekot, Kraków 2009, (,Seria Cultura”), zwłaszcza s. 1-35, 147-173, 197-200, [oryg. Image and Pilgrimage in Christian Culture. Anthropological Perspectives, New York 1978 („Lectures on the history of religions, N.S.", vol. 11)].

26 Na zaistnienie takiej sytuacji wskazuje również przywoływana już wyżej treść odpowiedzi polskiego i litewskiego monarchy udzielona posłom zakonnym zapewne w 1411 r., zgodnie z którą obaj władcy uwolnienie Kazimierza V i Konrada VII uzależniali od zwolnienia przez stronę zakonna jeńców wziętych do niewoli zarówno przez wojska pruskiej, jak i inflanckiej gałęzi zakonu, por. CEVMDL I 467, s. 217.

27 Jednocześnie taki kontekst podróży Świętobora I pozwala na skromne rozszerzenie typologii motywów pielgrzymek, zob. N. Ohler, Pilgerstab und Jakobsmuschel..., s. 61-80; Ch. Hippler, Die Reise nach Jerusalem..., s. 65-79. Z sanktuarium św. Theobalda znana jest pielgrzymka rycerza Herswanka w 1408 r., którą odbył w podzięce 
do górnoalzackiego sanktuarium w Thann w 1408 r. związaną z chorobą księcia ${ }^{28} \mathrm{z}$ wyprawą lewantyńską w 1411 r., przedsięwzięciem trzykrotnie dłuższym, znacznie bardziej uciążliwym i bardziej kosztownym aniżeli podróż za górny Ren, wówczas zasadne będzie pytanie już nie tylko o motywy pielgrzymki, ale również o czynniki decydujące o wyborze jej celu. Być może uczucie ojca względem syna było tu jedynym determinantem decyzji. Wydaje się jednak, że możliwa jest bardziej zróżnicowana interpretacja - i ta jawi się jako właściwsza. Wybór Grobu Świętego jako celu wotywnej religijnej podróży Świętobora I stoi w bliskiej relacji do ówczesnych wyobrażeń konfliktu polsko-litewsko-zakonnego opartych o propagandowe działania zakonu. Konflikt ten był przezeń prezentowany jako wojna prowadzona w obronie chrześcijaństwa przeciwko litewskim „poganom”, ruskim „schizmatykom” i mongolskim „saracenom” występującym przeciwko zakonowi pod przywództwem wprawdzie chrześcijańskiego króla, który jednak właśnie poprzez owo wykorzystanie sił wrogów chrześcijaństwa sam jawił się i był przedstawiany jako wróg wiary. Bliższe badania problematyki wojny 1409-1411 r. przynoszą coraz to nowe przesłanki wskazujace na daleko idaca internalizację tego propagowanego przez zakon obrazu polskiego monarchy wśród licznych dostojników, panów i rycerzy z Rzeszy czy z ziem francuskich ${ }^{29}$. W tym kontekście również stosunek Świętobora I do Władysława II w 1410 i 1411 r. oraz ówczesne postrzeganie polskiego

za uwolnienie syna, por. N. Buske, Die Verehrung des Hl. Ewald..., s. 24; J. Zdrenka, Święty Teobald..., s. 404-405 (tu treść źródła).

${ }_{28}$ Kontekst możliwości peregrynacyjnych na Pomorzu w początkach XV w. rozszerza tu istotnie także Akwizgran, por. B. Schimmelppennig, Die Regelmäßigkeit mittelalterliche Wallfahrt [w:] Wallfahrt und Alltag in Mittelalter..., s. 94.

29 W. Paravicini, Von der Preußenfahrt zum Hussitenkreuzzug [w:] Beiträge zur Militärgeschichte des Preussenlandes von der Ordenszeit bis zum Zeitalter der Weltkriege, hg. v. B. Jähnig, Marburg 2010 (,Tagungsberichte der Historischen Kommission für ost- und westpreußische Landesforschung", Bd. 25), s. 121-122; idem, Vom Krezzug zum Soldzug: Die Schlacht bei Tannenberg und das Ende de Preußenfahrten des europäischen Adels [w:] Conflictus magnus apud Grunwald 1410. Między historia a tradycja. Materiaty z międzynarodowej konferencji naukowej „Grunwald $\square$ Tannenberg $\square$ Žalgiris” zorganizowanej $20 \square 24$ września 2010 r. w Malborku i Krakowie, red. K. Ożóg, J. Trupinda, Malbork 2013, s. $119 \square 126$; S. Gouguenheim, Das Echo der Schlacht bei Grunwald im Frankreich des XV. und XVI. Jahrhunderts [w:] Conflictus magnus apud Grunwald 1410..., s. 193-199; K. Kwiatkowski, Durch Got lub umb solt - „goście” i najemnicy $w$ stużbie zakonu niemieckiego $w$ Prusach w 1410-1411 r. Druga część edycji „Ksiegi żołdu” Svena Ekdahla, „Studia Źródłoznawcze” 2012, t. 50, s. 126-128; idem, „Memoria continenter historiam denotat". Bitwa pod Grunwaldem/Tannenbergiem/Žalgirisem 1410 w najnowszych badaniach, RTNT 2015, R. 95, z. 1, s. 118-119, 185-186. 
monarchy ze strony Gryfity ${ }^{30}$ wydają się podlegać oddziaływaniu tego psycho-społecznego fenomenu, potęgowane jeszcze przez indywidualne przeżycia księcia-ojca ${ }^{31}$. Jest zatem możliwe, że Świętobor I udawał się wiosną 1411 r. do Palestyny w przekonaniu, że u Grobu Świętego, o który liczni chrześcijanie walczyli z wrogami wiary, uzyska nadprzyrodzoną łaskę uwolnienia syna pozostającego w niewoli u jednego ze współczesnych mu prześladowców chrześcijaństwa.

Ukazany w niniejszym artykule indywidualny przypadek, dotyczący wprawdzie członka ówczesnych elit społecznych, rzucający jednak snop światła na ówczesną mentalność w szerszym wymiarze, jawiąca się zresztą jako typowy wyraz późnośredniowiecznej religijności świeckiej $^{32}$, w swoich mikrohistorycznych ramach stanowi wartościowy asumpt dla ogólnego stwierdzenia o antropologiczno-kulturowym wymiarze - mianowicie, że niezależnie od historycznych narracji o starciach bitewnych, które tak przez zwycięzców, jak i zwyciężonych były kreślone zazwyczaj w nurcie bohaterskim bądź też z uwagi nań były przemilczane, i które jako takie stanowiły przez długie dziesięciolecia ramy funkcjonowania kolektywnej pamięci historycznej (a często nadal stanowia) ${ }^{33}$, za każdą walką zbrojną kryją się nie tylko wzniosłe

30 Należy zauważyć, że mielibyśmy tu do czynienia z fenomenem chwilowym, na który niewielki wpływ miały wcześniejsze kontakty interpersonalne obu władców (w 1395, 1396 i 1409 r.), którzy mogli znać się całkiem dobrze, por. J. Zdrenka, Annäherung Polens, Litauens und Pommerns im J. 1396, BS NF 1986, Bd. 72, s. 24-35; idem, Itinerar des Stettiner Herzogs Swantibor I...., s. 182, 190.

31 Przywoływany list książęcy z 18.10.1410 r. zdaje się zawierać pewien symptomatyczny w tym kontekście zwrot, którego nie można kłaść wyłącznie na karby stylistyki bądź kurtuazyjnego schlebiania adresatowi. Mianowicie książę wyraża radość z faktu opuszczenia przez siły króla polskiego kraju pruskiego i odbicia przez komtura świeckiego i jego zakon miejscowych zamków, uwypukloną jednakże zastosowaniem formuły laudacyjnej: „Nu der konich, got sy ghelobet, wydder wech gherumet ist, alzo daz ir euwer slozze von des euwern wedder macht habt", por. GSPK, XX. HA, OBA 1374. Czy Świętobór I nie wyraża tym samym pośrednio przekonania co do sprawiedliwego charakteru konfliktu prowadzonego ze strony zakonu niemieckiego?

32 W kwestii wzajemnych uwarunkowań fenomenu religijności wśród świeckich elit i mas por. podstawowe studium, K. Schreiner, Laienfrömmigkeit-Frömmigkeit von Eliten oder Frömmigkeit des Volkes? Zur sozialen Verfaßheit laikaler Frömmigkeitspraxis im späten Mittelalter [w:] Laienfrömmigkeit im späten Mittelalter. Formen, Funktionen, politisch-soziale Zusammenhänge, hg. v. K. Schreiner, E. Müller-Lucker, München 1992 (,Schriften des Historischen Kollegs, Kolloquien”, Bd. 20), s. 1-78.

33 Fenomen ten najbardziej intensywny pod względem medialnym wymiar przybrał zwłaszcza w epoce rodzących się i rozwiniętych nacjonalizmów XIX i XX stulecia, por. m.in. R. Schilling, „Kriegshelden”. Deutungsmuster heroischer Männlichkeit in Deutschland 1813-1945, Paderborn-München-Wen-Zürich 2002 („Krieg in der Geschichte”, Bd. 15), aczkolwiek nie jest on wyłącznie jej explicite przypisany 
uczucia towarzyszące wspólnemu przeżywaniu momentów zagrożenia życia ${ }^{34}$, ale także - a może przede wszystkim - indywidualny podły los wielu ocalałych z niej uczestników oraz w dalszej kolejności osób z ich najbliższego otoczenia społecznego. W tym sensie starcie bitewne niemal każdorazowo ma niezmienny wymiar antropologiczno-kulturowy. W wymiarze tym psychospołeczne oddziaływanie krwawych wydarzeń na ludzkie jednostki często - aczkolwiek nie zawsze i nie bynajmniej jako fenomen obiektywny kulturowo - pozostaje niezwykle trwałym ich następstwem - i jako takie zostało dla zachodniego kręgu kulturowego szeroko już przeanalizowane przez badaczy czasów nowożytnych ${ }^{35}$. Niemniej jednak daje się ono pośrednio zauważyć także w rozważanym tu przypadku bitwy grunwaldzkiej, zyskując tym samym odniesienie także do późnego średniowiecza.

\section{Abstract}

\section{The Captivity of Casimir [V], Duke of Pomerania-Stettin, after the Battle of Grunwald (1410/1411): Historic and Cultural Observations}

The paper presents the activities of Swantibor I, Duke of Pomerania, undertaken in relation to the captivity of his son, the young Griffin Casimir [V], by the King of Poland, Władysław II, after the Battle of Grunwald on July 15, 1410; it also verifies the erroneous opinions present in the older literature regarding the period of Casimir's imprisonment (1410-1411) and indicates sources which confirm that in 1411 Swantibor I

i ma raczej wymiar antropologiczny, por. ostatnio M. Clauss, Kriegsniederlagen im Mittelalter. Darstellung - Deutung - Bewältigung, Paderborn-München-WienZürich 2010 („Krieg in der Geschichte”, Bd. 54), gdzie w różnych miejscach przeanalizowano problematykę tematyzacji obecności bohaterów w średniowiecznych starciach kończących się porażka.

34 E. Fromm, Anatomia ludzkiej destruktywności, tłum. Jan Karłowski, Poznań 1999, s. 231-237 [oryg. The Anatomy of Human Destructiveness, Michigan 1973]; por. także A. du Picq, Studyum o walce, tłum. J. Zając, wyd. I Warszawa 1927; wyd. II Oświęcim 2012, s. 11 [oryg. Études sur le combat, Paris 1880].

35 Z licznych prac por. m.in. zbiór studiów: Kriegsgreuel. Die Entgrenzung der Gewalt in kriegerischen Konflikten vom Mittelalter bis ins 20. Jahrhundert, hg. v. S. Neitzel, D. Hohrath, Paderborn-München-Wien-Zürich 2008 (,Krieg in der Geschichte”, Bd. 40); H. Peterse, „Süß scheint der Krieg den Unerfahrenen“. Erasmus von Rotterdam über Krieg und Frieden [w:] Süß scheint der Krieg den Unerfahrenen. Das Bild vom Krieg und die Utopie des Friedens in der Frühen Neuzeit, hg. v. H. Peterse, V. Marschall, Osnabrück 2006, s. 9-23. 
went on a pilgrimage to the Holy Land. Taking into account the old age of the Pomeranian monarch, his poor health, the several-months-long break in performing monarchic functions in his Duchy and gubernatorial functions in the Mittelmark, the geographical expanse of the journey, as well as its very destination - i.e., the sanctuaries, first and foremost the Holy Sepulchre in Jerusalem - this journey, distant and in many aspects dangerous for the old Duke, should be interpreted as a paternal votive pilgrimage in the intention of recovering his son. We also pointed at some indications that the votive pilgrimage of Swantibor I was motivated not only by his paternal feelings for his son, but that the decision to visit the Holy Sepulchre resulted from the old Duke's perception of the Polish-Lithuanian-Teutonic conflict and the King of Poland himself. The latter, keeping his son imprisoned, most likely in the distant Lithuania, presented himself to him as an enemy of Christianity availing himself of "pagans", "schismatics", and "Saracens" in the fight with the German order, whom both Griffins supported. In this situation, only a remarkable votive deed performed in the hope of eliciting direct divine intervention could have saved the son and return him to his father. This action of Swantibor I and its motives wholly inscribe themselves into the religious mentality of the then elite and their perception of reality. 